\title{
AN EXPERIMENTAL DESIGN METHOD FOR THE EXTRACTION OF EURYCOMANONE FROM TONGKAT ALI (Eurycoma longifolia) ROOTS USING PRESSURISED LIQUID EXTRACTION (PLE)
}

\author{
(Kaedah Reka bentuk Eksperimen bagi Pengekstrakan Eurikomanon daripada Akar Tongkat Ali \\ (Eurycoma longifolia) Menggunakan Pengekstrakan Cecair Tekanan Tinggi) \\ Rozita Osman*, Norashikin Saim, Mardiana Saaid, Nor Nasriah Zaini \\ Faculty of Applied Sciences, \\ Universiti Teknologi MARA, 40450 Shah Alam, Selangor, Malaysia \\ *Corresponding author: rozit471@salam.uitm.edu.my
}

Received: 24 February 2015; Accepted: 27 October 2015

\begin{abstract}
Pressurised liquid extraction (PLE) method was utilised to extract eurycomanone from Tongkat Ali root (Eurycoma longifolia) using water as extraction solvent. Optimisation of PLE operating parameters was conducted using three-factor response surface experimental design to evaluate the interactive effects of temperature $\left(90-150{ }^{\circ} \mathrm{C}\right)$, extraction time $(10-30 \mathrm{~min})$ and pressure $(850-1700 \mathrm{psi})$ on the yield of eurycomanone. Online solid phase extraction - high performance liquid chromatography (SPEHPLC) with a diode array detector (DAD) was used for the separation and detection of this compound. Extraction temperature was found significant in increasing the yield of eurycomanone. Based on maximum yield of eurycomanone, the optimum operating extraction conditions for PLE were set up at temperature $\left(106^{\circ} \mathrm{C}\right)$, pressure $(870 \mathrm{psi})$ and static time $(30 \mathrm{~min})$. The amount of eurycomanone from Tongkat Ali root samples of various sources was analysed using the optimised PLE conditions.
\end{abstract}

Keywords: pressurised liquid extraction, Eurycoma longifolia, eurycomanone, solid phase extraction - liquid chromatography

\begin{abstract}
Abstrak
Kaedah pengekstrakan cecair tekanan tinggi (PLE) telah digunakan untuk mengekstrak eurikomanon daripada akar Tongkat Ali (Eurycoma longifolia) menggunakan air sebagai pelarut. Pengoptimuman parameter operasi PLE dijalankan dengan menggunakan reka bentuk eksperimen gerak balas permukaan tiga faktor untuk menilai kesan interaktif suhu $\left(90-150{ }^{\circ} \mathrm{C}\right)$, masa pengekstrakan $(10-30 \mathrm{~min})$ dan tekanan $(850-1700$ psi) ke atas hasil eurikomanon. Pengekstrakan fasa pepejalkromatografi cecair tekanan tinggi (SPE-HPLC) dengan pengesan diod (DAD) telah digunakan untuk pemisahan dan pengesanan sebatian ini. Suhu pengekstrakan didapati penting dalam meningkatkan hasil eurikomanon. Berdasarkan hasil maksimum eurikomanon, pengkstrakan optimum untuk PLE, ialah suhu $\left(106{ }^{\circ} \mathrm{C}\right)$, tekanan $(870 \mathrm{psi})$ dan masa static $(30$ minit). Amaun eurikomanon daripada pelbagai sampel akar Tongkat Ali telah dianalisis dengan menggunakan keadaan PLE yang telah dioptimumkan.
\end{abstract}

Kata kunci: pengekstrakan cecair tekanan tinggi, Eurycoma longifolia, eurikomanon, pengekstrakan fasa pepejal kromatografi cecair

\section{Introduction}

Eurycoma longifolia or commonly known as Tongkat Ali or pasak bumi is a flowering plant in the family Simaroubaceae, native to Indonesia, Malaysia, Thailand, Vietnam, and Laos. The tree grows up to 12 meters in 


\section{Rozita et al: AN EXPERIMENTAL DESIGN METHOD FOR THE EXTRACTION OF EURYCOMANONE FROM TONGKAT ALI (Eurycoma longifolia) ROOTS USING PRESSURISED LIQUID EXTRACTION (PLE)}

height. Various bioactive constituents have been isolated and charaterised from Eurycoma longifolia, mostly from roots such as canthin-6-one alkaloids, $\beta$-carboline alkaloids, quassinoids, triterpenes, squalene derivatives, biphenylneolignans, eurycolactone, laurycolactone and eurycomalactone [1-5]. Quassinoids form the major bioactive constituents in this plant [6] and are mainly responsible for its bitter taste [1,7]. Eurycomanone (Figure 1), is found in the roots of Eurycoma longifolia have been traditionally used for its potential antimalarial, aphrodisiac, anti-diabetic and anti-microbial activities [8]. Among bioactive components of Tongkat Ali, eurycomanone has the highest concentration [9]. Thus, this compound is more commonly used as the marker compound for Tongkat Ali extract quantification [10].

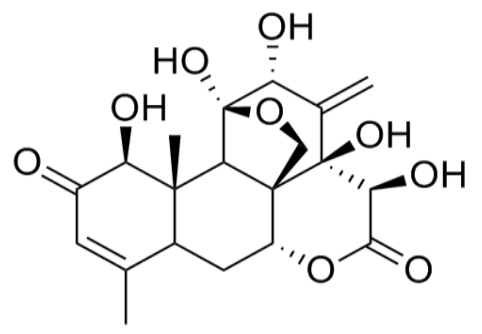

Figure 1. Chemical structure of eurycomanone

Typically, bioactive compounds are isolated using a series of processes beginning with extraction, which involves the transfer of solutes from a solid to a solvent. The ideal extraction system should be quantitative, non-destructive and time saving [11]. Several extraction techniques were reported such as Soxhlet extraction [12] and supercritical fluid extraction [13]. Soxhlet extraction is one of the oldest techniques for isolating metabolites from natural materials. It allows a high yield, but has a number of shortcomings, including long extraction time and large consumption of solvents, cooling water and electric energy. The disposal of waste solvents is also hazardous and very costly. Consequently, there is an increasing demand for new extraction techniques with possibilities for automation, shorter extraction time and lower solvent consumption. Pressurised liquid extraction (PLE), also known under the Dionex trade name accelerated solvent extraction (ASE), is currently attracting interest due to its rapid extraction time $(5-30 \mathrm{~min})$, a reasonable working temperature that can be optimised to achieve the desired extract, its simplicity, ability to be automated, low cost and its favourable environmental impact because of low solvent use [14]. The technique uses organic solvent or water at elevated temperature and pressure, which drastically improves the speed of the extraction process [15]. The high pressure allows maintaining the solvent in a liquid state at a high temperature. Under these conditions, the solvent has properties favouring the extraction process, and high solvent strength. Traditionally, the optimisation of factors affecting the extraction of active compounds can be achieved by studying each factor separately. However, through the application of chemometric, based on the use of central composite design (CCD) and multilinear regression analysis, an optimisation study that incorporates individual factors and also interactions of extraction temperature, pressure and static time can be obtained efficiently. The aim of this work is to determine an optimised pressurised liquid extraction method using experimental design for the extraction of eurycomanone from Tongkat Ali roots.

\section{Plant Material}

\section{Materials and Methods}

The roots of Eurycoma longifolia were provided by local suppliers. Samples were dried and ground before sieved into the size of $2.4 \mathrm{~mm}$. The ground samples were stored at $-20{ }^{\circ} \mathrm{C}$ until analysis.

\section{Chemicals}

Eurycomanone reference standard was purchased from Chromadex (Irvine, California). Stock standard solution containing $500 \mu \mathrm{g} / \mathrm{mL}$ of eurycomanone was prepared in methanol and kept in amber vials at $-4{ }^{\circ} \mathrm{C}$ until use. Solvent used for PLE extraction was deionised water. For 2D-HPLC analysis, methanol, acetonitrile of HPLC grade were used, purchased from Merck (Germany). 


\section{Pressurised liquid extraction (PLE)}

Extractions were done using ASE 350 accelerated solvent extractor (Thermo Scientific Ltd. Camberly, Surrey, UK). The dried and ground roots of Eurycoma longifolia $(2 \mathrm{~g})$ was accurately weighed into $34 \mathrm{~mL}$ extraction cells. The sample cells were then closed and placed into the carousel of the ASE 350 system. Extractions were done using water. The extraction conditions (temperature, pressure and extraction time) were optimised using an experimental design approach based on the marker compound (eurycomanone). The cell was rinsed with water (about $60 \%$ of extraction cell volume). The extract was filtered and kept in a freezer at $-20{ }^{\circ} \mathrm{C}$ prior to online SPE-HPLC analysis.

\section{Experimental design}

The experimental design was generated using Design-Expert version 6.0.4 (Stat Ease Software). The central composite design (CCD) with 5 coded levels; $-\alpha,-1,0,+1$ and $+\alpha$ was used. A total of 20 experiments (14 points of factorial design, and 6 center points) were carried out in randomised run order. The level of variables chosen for central composite design was assigned limits as shown in Table 1. The response variable (amount of eurycomanone) was evaluated by using response surface methodology (RSM).

Table 1. Central Composite Design used for the extraction of eurycomanone from Tongkat Ali roots

\begin{tabular}{cccc}
\hline $\begin{array}{c}\text { Coded } \\
\text { level }\end{array}$ & $\begin{array}{c}\text { Temperature } \\
\left({ }^{\circ} \mathbf{C}\right)\end{array}$ & $\begin{array}{c}\text { Pressure } \\
(\mathbf{P s i})\end{array}$ & $\begin{array}{c}\text { Extraction time } \\
(\mathbf{m i n})\end{array}$ \\
\hline$-\alpha$ & 69.5 & 560 & 3 \\
-1 & 90 & 850 & 10 \\
0 & 120 & 1275 & 20 \\
1 & 150 & 1700 & 30 \\
$+\alpha$ & 170.5 & 1990 & 37 \\
\hline
\end{tabular}

\section{SPE-HPLC separation}

Chromatographic separation was performed on a Dionex Ultimate 3000 Liquid Chromatography System on Dionex Ion Pac AG14A (4 x $50 \mathrm{~mm})$, Dionex $\mathrm{C}_{18}(5 \mu \mathrm{m}$ x $4.6 \mathrm{~mm}$ x $50 \mathrm{~mm})$, and Acclaim Polar C18 $(5 \mu \mathrm{m}$ x $4.6 \mathrm{~mm}$ x 250 $\mathrm{mm})$ columns. The mobile phase comprised of pure water (A), methanol (B) and acetonitrile (C) $(0-5.7 \mathrm{~min}$ : isocratic $70 \% \mathrm{~A}: 30 \% \mathrm{C} ; 5.7-8.5$ min: gradient elution to $30 \% \mathrm{~A}: 70 \% \mathrm{C} ; 8.5-16$ min: gradient elution $30 \%$ A: $70 \%$ B to $60 \%$ A: $40 \%$ B; $16-19$ min: gradient elution $50 \%$ B: $50 \%$ C to $10 \%$ B: $90 \%$ C; $19-25$ min: isocratic $10 \% \mathrm{~B}: 90 \% \mathrm{C}$ ), with flow rate kept at $1 \mathrm{~mL} / \mathrm{min}$. The column temperature was kept at $37{ }^{\circ} \mathrm{C}$ in an oven. Eluted compounds were monitored over a wavelength range of $200-400 \mathrm{~nm}$. Figure 2 shows the chromatogram of standard eurycomanone separated using online SPE-HPLC.

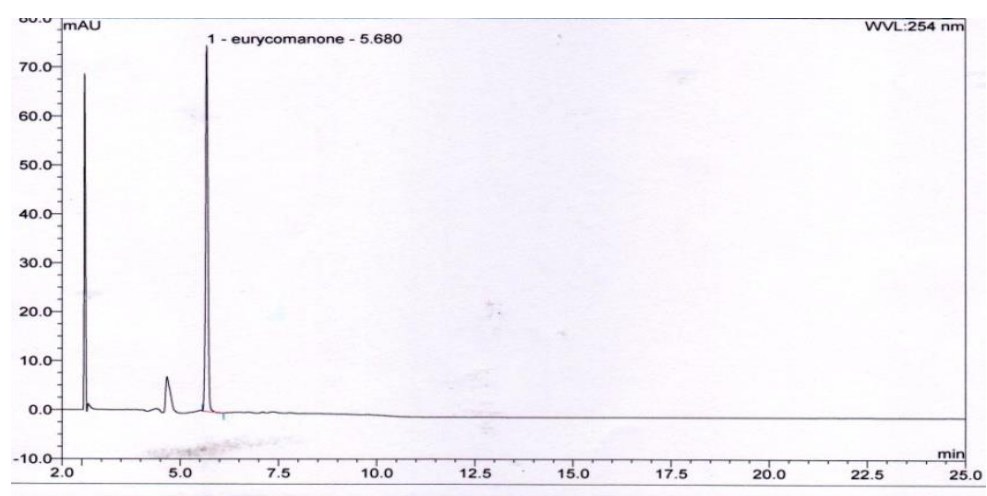

Figure 2. Chromatogram of standard eurycomanone $(50 \mu \mathrm{g} / \mathrm{mL})$ 


\section{Rozita et al: AN EXPERIMENTAL DESIGN METHOD FOR THE EXTRACTION OF EURYCOMANONE FROM TONGKAT ALI (Eurycoma longifolia) ROOTS USING PRESSURISED LIQUID EXTRACTION (PLE)}

\section{Optimization of PLE operating parameters}

\section{Results and Discussion}

Multilinear regression was applied to the results of the central composite design. The results were based on the amount of eurycomanone obtained from the extract as shown in Table 2. The effect of independent variables; extraction temperature $(\mathrm{T})$, extraction time $(\mathrm{t})$ and pressure $(\mathrm{P})$ on the amount of eurycomanone was evaluated by second order (quadratic) and interactive effect (interaction between pairs of variables) (Table 3). The adequacy of the model were determined using model analysis, lack of fit test and coefficient of determination $\left(\mathrm{R}^{2}\right)$. ANOVA result showed that the model was significant, $\mathrm{p}<0.05(\mathrm{p}=0.037)$ with not significant lack of fit, $\mathrm{p}>0.05(\mathrm{p}=$ 0.0501). The significance of the equation parameters for each response variable was also assessed by F-ratio at a probability (p) of 0.05 . The closer the value of $\mathrm{R}^{2}$ to unity, the better the empirical model fits the actual data. Criteria for a good fit of a model, the $\mathrm{R}^{2}$ should be at least 0.80 [16]. In this study, the $\mathrm{R}^{2}$ was 0.8923 . The high value of $R^{2}(>0.80)$ indicates the adequacy of the applied quadratic model.

Table 2. Results of the CCD for the analysis of Tongkat Ali Roots

\begin{tabular}{|c|c|c|c|c|}
\hline \multirow[t]{2}{*}{ No. } & \multicolumn{3}{|c|}{ Factor } & \multirow{2}{*}{$\frac{\text { Compound }}{\underset{(\mu \mathrm{g} / \mathrm{g})}{\text { Eurycomanone }}}$} \\
\hline & $\begin{array}{c}\text { Temperature, } \\
\text { T }\left({ }^{\circ} \mathbf{C}\right)\end{array}$ & $\begin{array}{c}\text { Extraction Time, } \\
\text { t (min) }\end{array}$ & $\begin{array}{l}\text { Pressure, } \\
\text { P (Psi) }\end{array}$ & \\
\hline 1 & 120.0 & 20.0 & 1275.0 & 407.72 \\
\hline 2 & 90.0 & 10.0 & 850.0 & 361.74 \\
\hline 3 & 120.0 & 20.0 & 1275.0 & 406.33 \\
\hline 4 & 150.0 & 30.0 & 850.0 & 286.87 \\
\hline 5 & 90.0 & 30.0 & 1700.0 & 289.38 \\
\hline 6 & 150.0 & 10.0 & 1700.0 & 399.55 \\
\hline 7 & 120.0 & 20.0 & 1275.0 & 382.67 \\
\hline 8 & 120.0 & 20.0 & 1275.0 & 425.03 \\
\hline 9 & 150.0 & 10.0 & 850.0 & 362.56 \\
\hline 10 & 90.0 & 10.0 & 1700.0 & 374.23 \\
\hline 11 & 150.0 & 30.0 & 1700.0 & 363.07 \\
\hline 12 & 90.0 & 30.0 & 850.0 & 390.31 \\
\hline 13 & 69.5 & 20.0 & 1275.0 & 306.33 \\
\hline 14 & 120.0 & 37.0 & 1275.0 & 450.24 \\
\hline 15 & 120.0 & 20.0 & 1990.0 & 390.24 \\
\hline 16 & 170.5 & 20.0 & 1275.0 & 164.76 \\
\hline 17 & 120.0 & 20.0 & 1275.0 & 370.53 \\
\hline 18 & 120.0 & 20.0 & 560.0 & 431.24 \\
\hline 19 & 120.0 & 20.0 & 1275.0 & 370.53 \\
\hline 20 & 120.0 & 3.0 & 1275.0 & 395.75 \\
\hline
\end{tabular}


Table 3. Multilinear Regression Results for analysis of eurycomanone in Tongkat Ali roots

\begin{tabular}{cc}
\hline Variable & P value \\
\cline { 2 - 2 } & Eurycomanone \\
\hline $\mathrm{T}$ & 0.1614 \\
$\mathrm{t}$ & 0.6369 \\
$\mathrm{P}$ & 0.7850 \\
$\mathrm{~T}^{2}$ & $\mathbf{0 . 0 0 1 0}$ \\
$\mathrm{t}^{2}$ & 0.3824 \\
$\mathrm{P}^{2}$ & 0.6062 \\
$\mathrm{Tt}$ & 0.6535 \\
$\mathrm{TP}$ & 0.1311 \\
$\mathrm{tP}$ & 0.5532 \\
\hline
\end{tabular}

Variation in extraction temperature $\left(\mathrm{T}^{2}\right)$ revealed that the increase in temperature resulted in a higher amount of eurycomanone extracted but reached a maximum value, with no significant further improvement thereafter as shown in Figure 3a and 3b. Pressure $(P)$ and static time $(t)$ were found not significant $(P>0.05)$ in the extraction of eurycomanone from Tongkat Ali root samples.

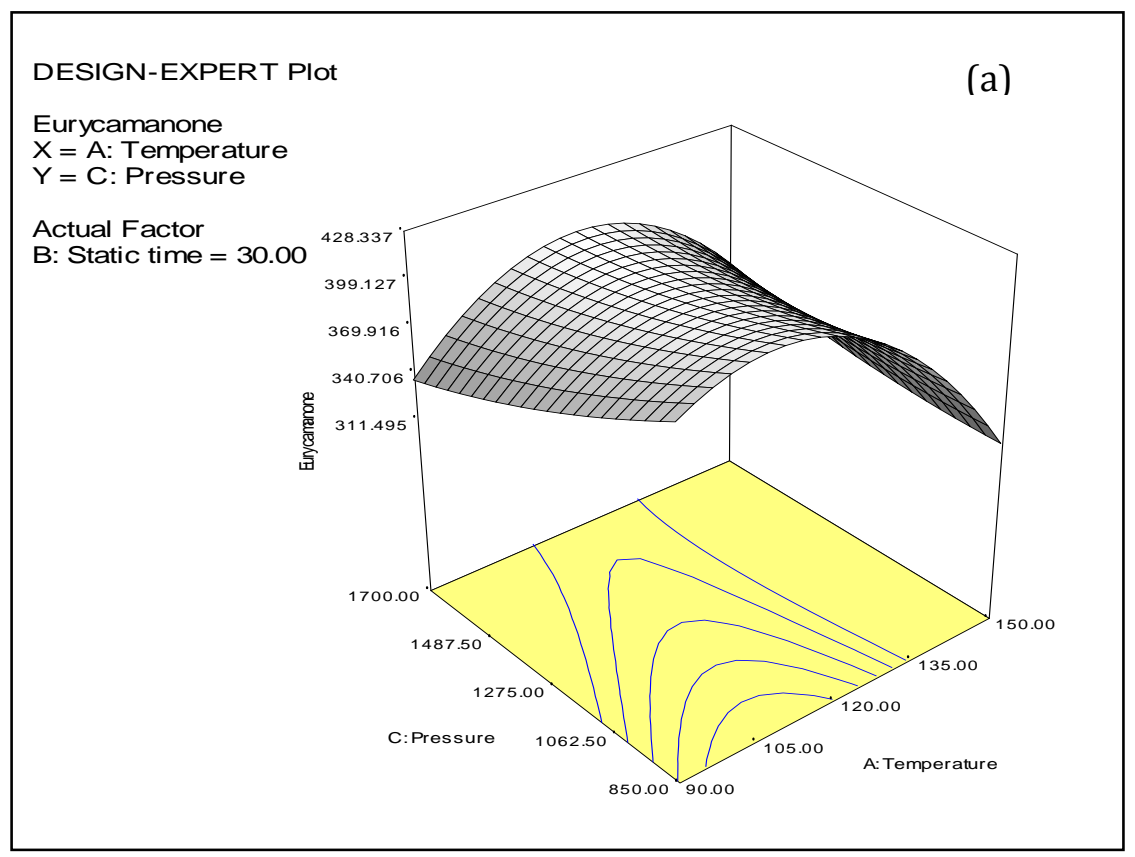




\section{Rozita et al: AN EXPERIMENTAL DESIGN METHOD FOR THE EXTRACTION OF EURYCOMANONE FROM TONGKAT ALI (Eurycoma longifolia) ROOTS USING PRESSURISED LIQUID EXTRACTION (PLE)}

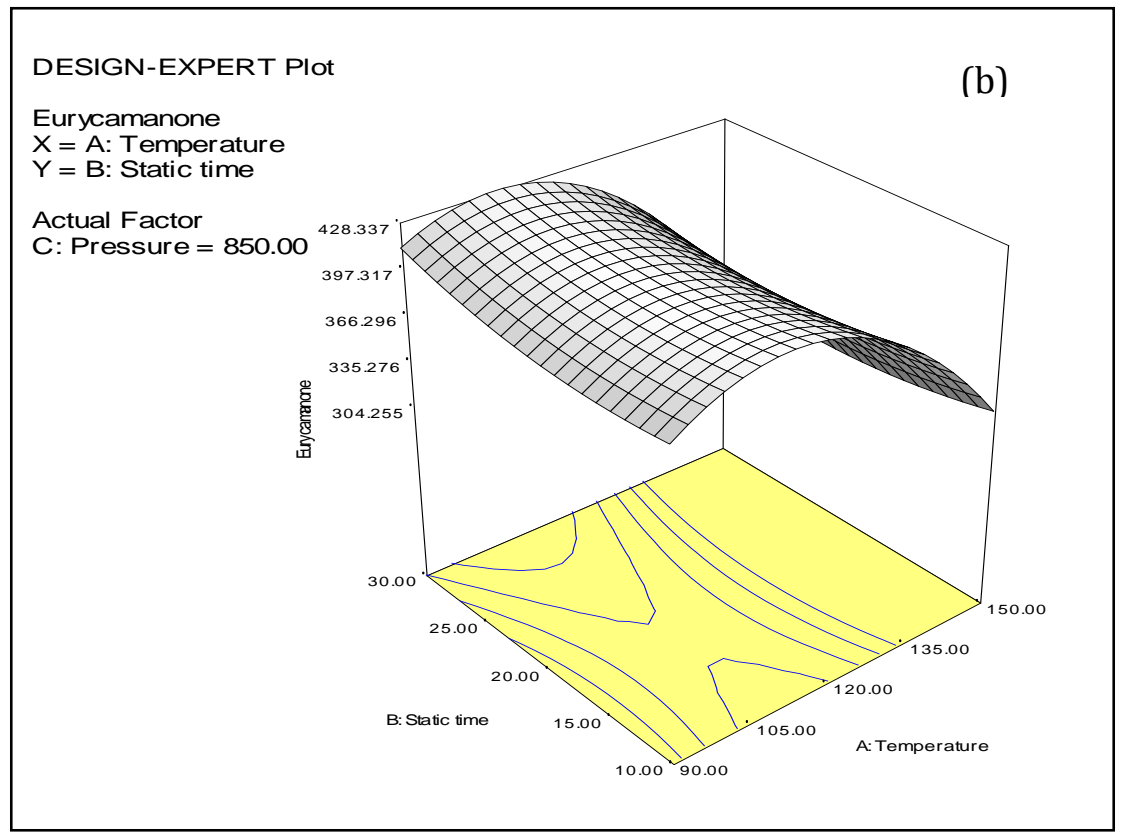

Figure 3. Contour and response surface plot of pressure against temperature (a) and static time against temperature (b) of eurycomanone obtained using Central Composite Design

Extraction temperature has a profound effect of the PLE process as reported by previous researcher [17]. Pressure is a minor variable for the resultant efficiency and it is only required to maintain the extractant in the liquid phase. The SPE-HPLC results obtained from this study indicate that the concentration of the eurycomanone increased significantly $(\mathrm{p}<0.05)$ with temperature (Table 1$)$. The results concurred with those reported by Gamiz-Gracia and de Castro [18]. In general, more components are extracted when the temperature is elevated, brought about by increasing solubility.

\section{Analysis of Tongkat Ali Roots}

Several sample of Tongkat Ali roots from different sources were extracted using the PLE optimum parameters at temperature of $106^{\circ} \mathrm{C}$, pressure of $850 \mathrm{psi}$ and a static time of $30 \mathrm{~min}$. Figure 4 shows the chromatograms of Tongkat Ali root extracts obtained from different sources. 

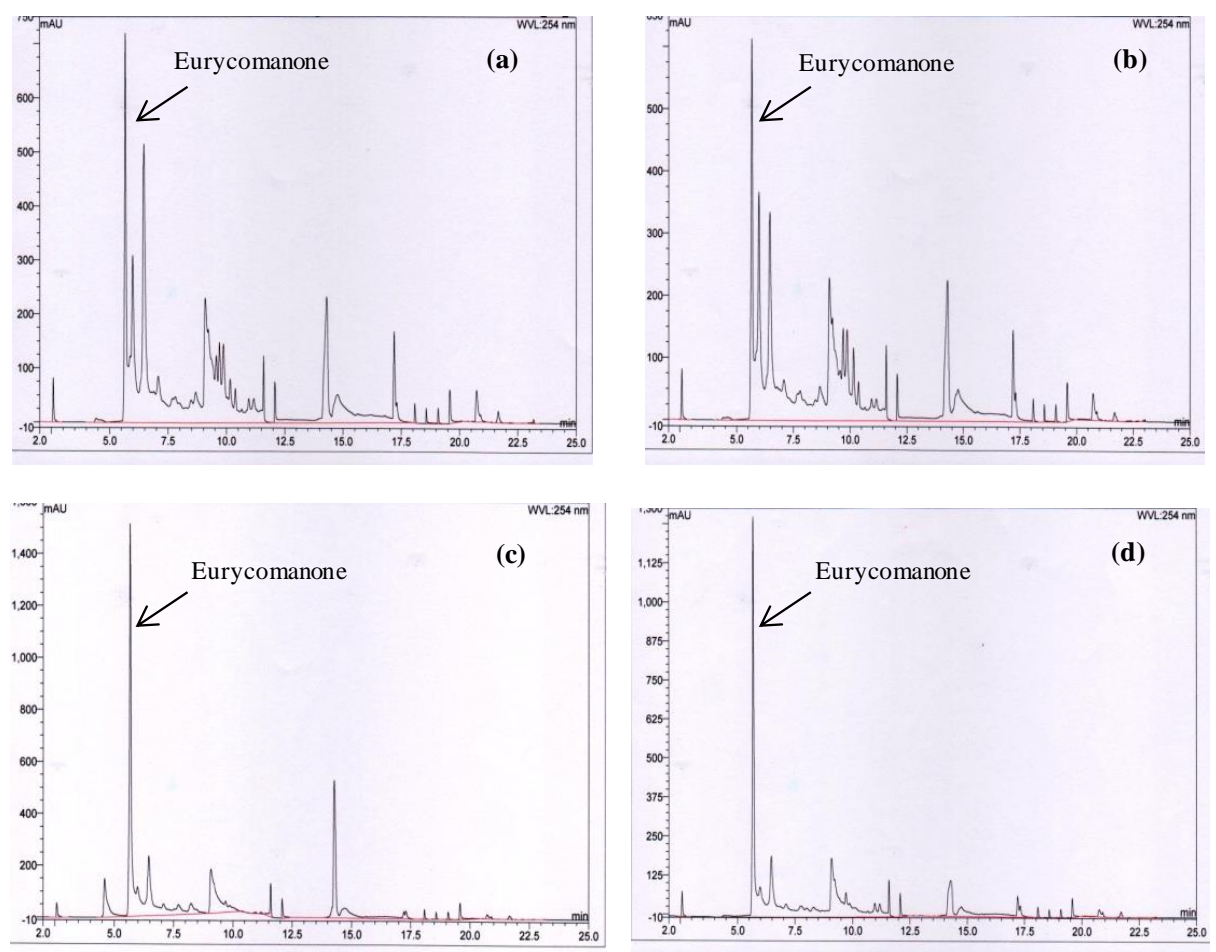

Figure 4. Chromatograms of Tongkat Ali roots of (a) Jengka sample 1(b) Jengka sample 2 (c) Taman Negara sample and (d) Sarawak sample

Figure 5 reveals the amount of eurycomanone extracted from Tongkat Ali root samples obtained from various places in Malaysia. The variation in the amount of eurycomanone in these samples may be due to harvesting age and sources [19].

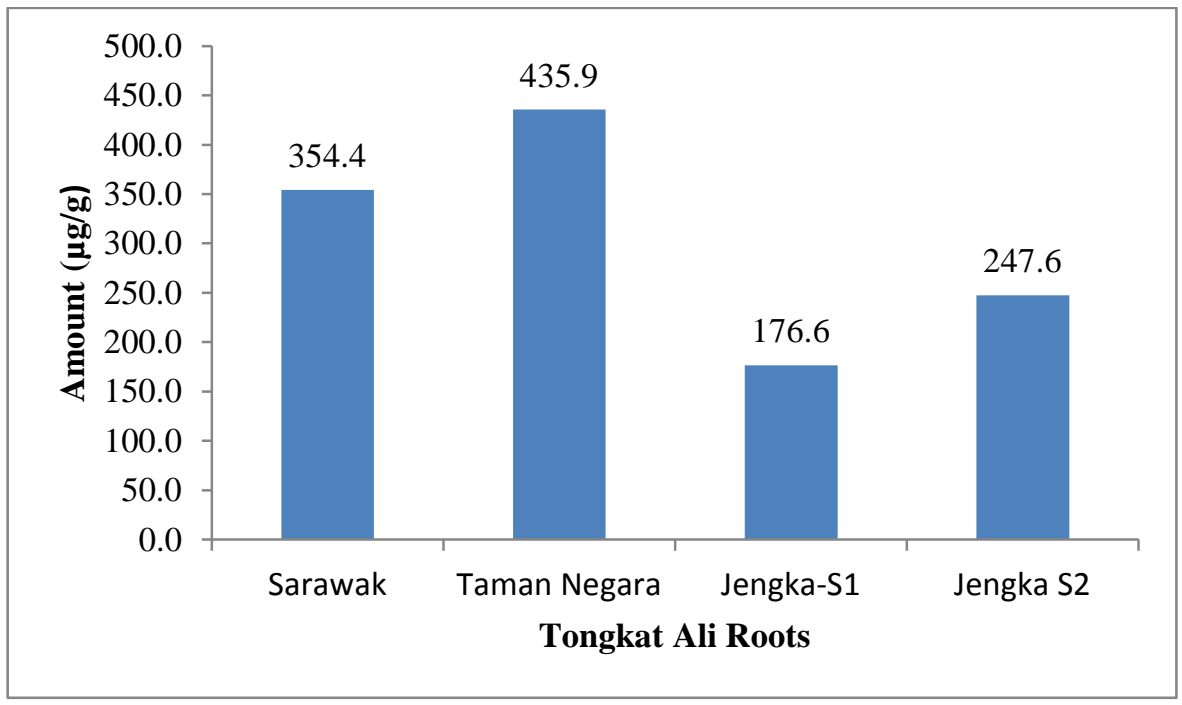

Figure 5. Amount of eurycomanone $(\mu \mathrm{g} / \mathrm{g})$ obtained from Tongkat Ali root samples 


\section{Rozita et al: AN EXPERIMENTAL DESIGN METHOD FOR THE EXTRACTION OF EURYCOMANONE FROM TONGKAT ALI (Eurycoma longifolia) ROOTS USING PRESSURISED LIQUID EXTRACTION (PLE)}

\section{Conclusion}

Pressurised liquid extraction (PLE) of Tongkat Ali roots was optimised. The PLE method offers important advantages over conventional methods, namely, shorter extraction time (17 min compared to $16 \mathrm{~h}$ for Soxhlet extraction), less solvent volumes employed (about $33 \mathrm{~mL}$ for PLE compared to $150 \mathrm{~mL}$ for Soxhlet extraction) and lower cost (energy cost is higher for Soxhlet extraction) and the possibility of manipulating the composition of the extract by changing the extraction parameters. This extraction method may contribute to the automation in food industry.

\section{Acknowledgement}

The authors would like to acknowledge the financial support obtained from Ministriy of Higher Education (600RMI/FRGS 5/3 (48/2014)) and Research Management Institute (RMI) Universiti Teknologi MARA.

\section{References}

1. Bedir, E., Abou-Gazar, H., Ngwendson, J. N. and Khan, I. A. (2003). Eurycomanoside: a new Quassinoids-type glycoside from the roots of Eurycoma longifolia. Chemical Pharmaceutical Bulletin, 51(11): 1301 - 1302.

2. Ang, H. H., Hitotsuyanagi, Y., Fukaya, H. and Takeya, K. (2002). Quassinoids from Eurycoma longifolia. Phytochemistry, 59:833-837.

3. Morita, H., Kishi, E., Takeya, K., Itokawa, H. and Iitaka, Y. (1993). Squalene derivatives from Eurycoma longifolia. Phytochemistry, 34:765 - 771.

4. Itokawa, H., Qin, X. R., Morita, H. and Takeya, K. J. (1993). C18 and C19 Quassinoids from Eurycoma longifolia. Journal of Nature Products, 56: 1766 - 1771.

5. Kardono, L. B. S., Angerhofer, C. K., Tsauri, S., Padmawinata, K., Pezzuto L. M., Kinghorn A. D. J. (1991). Cytotoxic and antimalarial constituents of the roots of Eurycoma longifolia. Journal of Nature Products, 54:1360 - 1367.

6. Jiwajinda, S., Santisopasri, V., Murakami, A., Kawanaka, M., Kawanaka, H. and Gasquet, M. 2002. In vitro anti-tumor promoting and anti-parasitic activities of the Quassinoids from Eurycoma longlifolia, a medical plant in Southeast Asia. Journal of Ethnopharmacology., 82:55 - 58.

7. Chan, K. L., Choo, C.Y., Abdullah, N. R. and Ismail, Z. (2004). Antiplasmodial studies of Eurycoma longifolia jack using the Lactare Dehydrogenase assay of Plasmodium Falciparum. Journal of Ethnopharmacology. 92: $223-227$.

8. Bhat, A and Karim, A. A. (2010). Tongkat Ali (Eurycoma longifolia Jack): a review on its ethnobotany and pharmacological importance. Fitoterapia, 81: 669 - 679.

9. Mohamad, M., Ali, M. W., Ripin, A. and Ahmad, A. (2013). Effect of extraction process parameters on the yield of bioactive compounds from the roots of Eurycoma longifolia. Jurnal Teknologi. 60:51 - 57.

10. Chan, K. L., Choo, C.Y., Morita, H. and Itokawa, H. (1998). High performance liquid chromatography in phytochemical analysis of Eurycoma longifolia. Planta Medica, 64(8): 741 - 745.

11. Zhang, S., Bi, H. and Liu, C. (2007). Extraction of bio-active components from Rhodiola Sachalinensis under ultrahigh hydrostatic pressure. Separation and Purification Technology, 57: 277 - 282.

12. Luque de Castro, M. D. and Garcia, L. E. (1998). Soxhlet extraction of solid materials: an outdated technique with a promising innovative future. Analytica Chimica Acta, 369: 1-10.

13. Cheah, E. L. C., Heng, P. W. S. and Chan, L. W. (2010). Optimization of supercritical fluid extraction and pressurized liquid extraction of active principles from Magnolia officinalis using the Taguchi design. Separation and Purification Technology, 71: 293 - 301.

14. Ozel, M. Z., Gogus, F. and Lewis, A. C. (2003). Subcritical water extraction of essential oils from Thymbra spicata. Food Chemistry, 82: $381-386$.

15. Ong, E. S. (2004). Extraction methods and chemical standardization of botanicals and herbal preparations. Journal of Chromatography B, 812: $23-33$.

16. Joglekar, A. M. and May, A. T. (1987). Product excellent through design of experiments. Cereal Foods World, 32: $857-868$.

17. Carabias-Martínez, R., Rodríquez-Gonzalo, E., Revilla-Ruiz, P. and Hernandez-Mendez, J. (2005). Pressurized liquid extraction in the analysis of food and biological samples. Journal of Chromatography A, 1089: 1 - 17. 
18. Gámez-Gracia, L., and Luque de Castro, M. D. (2000). Continuous subcritical water extraction of medicinal plant essential oil: comparison with conventional techniques. Talanta, 51: 1179-1185.

19. Joshi, K., Chavan, P., Warude, D and Patwardhan, B. (2004). Molecular markers in herbal drug technology. Current Science, 87(2): $159-165$. 